\title{
Theoretical Arguments and Debates on Public Enterprises Privatization: Ethiopian Focus
}

\author{
Fentaw Leykun ${ }^{1}$
}

\begin{abstract}
Purpose: To critically review the theoretical arguments and debates on privatization, challenges, and prospects in the Ethiopian context, and the various countries experience on privatization with especial focus on sub-Saharan countries and come up with valuable directions to undertake the privatization process successfully.

Design/Methodology/Approach: The entire review basis the theoretical end empirical literature published in various national and international reputable journals.

Findings: Privatization is not a recent phenomenon globally; different economies practiced it via arguing and debating in terms of its economic and political benefits. Currently, the government of Ethiopia is practicing economic reforms to get ready for the country to join middle-income countries by 2025 . In filling this gap, inter alia, the government has taken new initiative to privatize the existing wholly state-owned enterprises, both for local and foreign owners, with the primary objectives of limiting government's participation in the manufacturing and service sectors, and thereby realizing economic efficiency and competition, boosting foreign exchange, rising tax revenues, simplifying problems associated with costs of living through controlling inflation, reducing unemployment and alleviating the problem of good governance.

Practical Implications: Finally, it tried to forward sequential steps that the government of Ethiopia should follow at least to mitigate the common mistakes and to undertake the privatization process successfully by alleviating the fear of the citizens that those SOEs would be concerted in the hands of some oligarchies.

Originality/Value: the inferences made as a result of this review will offer new insights through which countries like Ethiopia, who are suffering from political unrest and enormous amount of unemployment, can justly distribute the wealth of public enterprises especially to the local citizens and thereby mitigate the unbalanced concentration of resources in the hands of some oligarchies.
\end{abstract}

Keywords: privatization; a state-owned enterprise; privatization debates; Ethiopia

DOI: $10.7176 / \mathrm{JESD} / 11-11-06$

Publication date:June 30th 2020

\section{Introduction}

The state in a given economy and within the existing sovereign power has a public purpose; exercising power in ensuring peace and security for the society, and protecting the country's sovereignty (traditional role); engaging in economic activities via setting up of business entities undertaking commercial activities (Mihret, n.d.). However, the rationale of why and the extent of such role of the state varies across countries in the world due to the political economy or ideology of the government. In the case of Ethiopia, the country's development strategy rests on the promotion of a free-market-oriented economy, although the state's arm in the economy is most noticeable than that of the private sector, the government manifests the lion's share of the economy. For example, the cash cow for government treasury, Ethiopian airlines, Ethiopian telecom, Ethiopian electric power corporation, Ethiopian insurance, Ethiopian shipping, and logistics enterprise, among others, are completely owned by the government until recently. However, the government of Ethiopia passed a decision on June 5, 2018, to privatize such giant public companies by transferring to both foreign and local investors with the main reason, among others, to alleviate the severe foreign exchange problem in the country.

The majority of the industrial public enterprises (IPEs) in Ethiopia today fell under state ownership as a result of the 1975 nationalizations. Of the rest, a few were state-owned even then; and some were established as state enterprises later on. IPEs dominate output, value-added, and employment in the manufacturing sector (Chole, 1993). Some of the economically inefficient firms are found to be financially profitable, leading the Bank to conclude that the financial profitability of the firms is not a good indicator of their economic efficiency (World Bank, 1985 as cited in Chole, 1993). As per Chole (1993), the failure of command economies on such a large scale has generated so much support for privatization that one seldom poses to ask what objectives are to be achieved by undertaking it.

Economic liberalization began before the fall of the Derge regime. Market-based reform initiated in December 1987; proceeded by a Soviet report calling for market-oriented pricing, marketing, and distribution of goods and services (Cheru, 1994; cited in Harvey, 1996). According to Harvey, the primary institutional changes proposed were very much less radical than elsewhere in Africa and is limited to the following: to allow private

\footnotetext{
${ }_{1}^{1}$ Associate Professor, Department of Accounting and finance, Faculty of Business and Economics, Bahir Dar university, Ethiopia, w.fentahun@gmail.com
} 
sector banks to operate, but only if $100 \%$ locally-owned, to allow the two development banks, Agricultural and Industrial Development Bank (AIDB) and the Housing and Savings Bank, to become commercial banks and to compete with the commercial bank of Ethiopia (CBE) and with each other, to give superior autonomy in lending decisions to CBE and to keep the three government banks (CBE, development bank of Ethiopia, and construction and business bank) in 100\% government ownership. Many reforms in the financial sectors, as one element of the service sector, have passed since then, though the majority of the shares belong to the government.

Since its inception in the year 1994, the privatization program of Ethiopia has gained gradual momentum and has evolved in certain economic perspectives such as allowing local private investors to join the financial segment even though the sector falls under the control of the state-owned bank, commercial bank of Ethiopia, however the gradual strategy of privatization still in line with the Ethiopian economic policy framework launched 27 years back, in the year 1991, with the justification to enhance the sustainable growth and development of the country's economy.

In the gradual process of privatization in Ethiopia, the agency is known as "the Ethiopian Privatization Agency (EPA)), was established 24 years back in the year 1994 by proclamation No. 87/1994 and 146/1998. Since then, the process of privatizing public-owned enterprises (POEs) has been delegated to EPA with the power and duties on investigating and making decisions on different claims of ownership concerning the properties taken in violation of the imperative proclamations; Proclamation No.110/1995 and its amendment proclamation No.193/2000. The agency is established to be administered by the board of directors and to be managed by the general manager and to be accountable to the ministry of trade and industry.

The establishment of the EPA was to accomplish the general objectives of generating sufficient revenue to finance development activities carried out by the government; to change the government's role and participation, and to divert its attention towards actions demanding more focus; to promote economic development via expanding and encouraging private sector's participating in the economy. Besides, EPA was responsible to accomplish the clearly defined tasks and duties as amended by Proclamation No. 146, issued on December 1998. This proclamation has got an amendment in the consecutive year of 1996 and later in 1998 by "Privatization of Public Enterprises Proclamation No. 146/98", aiming privatization in bringing sustainable economic development via creating a sufficient market and gradually reducing the government's involvement in the economy. Currently, EPA is merged with the then Ethiopian Public Enterprise Supervising Authority (PESA) to form the Ethiopian Privatization and Public Enterprises Supervising Authority (PPESA) in 2004 by Privatization and Public Enterprises Supervising Authority Establishment Proclamation No.412/2004. The PPESA is currently in charge of carrying out the public enterprises' privatization process in an efficient manner. The (PPESA) is an autonomous government official entrusted with the tasks of privatization, supervision, managing, assisting and controlling state-owned enterprises to make them competitive and profitable, and thereby qualifying them to play substantial roles in the application of the country's industrial development strategy and the improvement of economic growth.

Recently, with the vision by the Federal Democratic Government of Ethiopia to make the country a middleincome economy by 2025, the Ministry of Public Enterprises has been established by the proclamation no.916/2015 to provide for the definition of powers and duties of decision-making bodies of the Federal Democratic Republic of Ethiopia (FDRE) (proclamation no.916/2015). For that reason, the powers and duties which were given to the Privatization and Public Enterprises Supervising Agency by Proclamation No.25/1992 and regarding public enterprises and shares to be privatized, and the powers and responsibilities assumed to the Privatization Board by Proclamation No. 412/2004 were given to the Ministry of Public Enterprises. The justification behind this reform was that, in line with the developmental state policy of the country, the Ministry is believed to oversee and assists public enterprises who are accountable to other governmental bodies by studying their strengths and weaknesses and by sharing international experiences. Concerning enterprises responsible to the ministry, the Ministry has been given the responsibility to conducts the Privatization Program and have the power to ensure whether enterprises have developed strategic and annual plans in line with policies, strategies, and economic goals of the government, approve plans and monitors their implementation.

Privatization is a gradual process in the country of Ethiopia; 166 state-owned enterprises were privatized from 1996 up to December 2000 (Deneke, 2001), around 365 public enterprises have been privatized for the past two decades, since 1999, and both domestic and foreign investors have been participated in the investment, valued at 18 billion Ethiopian Birr (PPESA, News, 2015), 371 public enterprises have been privatized in the past two decades and have generated 24 Billion ETB (Simmons \& Simmons LLP, 2018). Recently, the Ministry of Public Enterprises (the Ministry) has tried to privatize around ten enterprises during the fiscal year 2016. Among others, Bahir Dar Textile S.C (via 1\% share sale), Combolcha Textile S.C (via 1\% share sale), Ethiopian crown Cork and Can manufacturing S.C (via 25\% share sale), and National Tobacco enterprise S.C (via $60 \%$ share sale) were the four state-owned enterprises already put for public tender. However, according to Simmons \& Simmons LLP 2018, out of these four companies, the two Textile share companies have failed to attract bidders, and then after the ministry had passed decisions to privatize such less attractive enterprises via negotiation approach. However, the gradual privatization program in Ethiopia evolves the risk of pooling public enterprises in the hand of few oligarchs 
(nazret.com, 2018).

In the light of the aforementioned ongoing activities of privatization, the federal democratic republic of Ethiopia executives committee have made their ordinary official meeting on 5/06/2018 in Addis Ababa, parliament hall. The committee has reported the economic advancement of the country for the past 15 years; the country has experienced the fast-growing and sustainable economy; as if such economies have motivated and initiated indigenous and overseas investors, this created a chance to strengthen local and foreign investment in the country. The committee has also evaluated and identified further economic activities that need emphasis henceforth in the growth and transformation plan two (GTP II) and then. Besides, the committee has appraised the activities performed for the past two and half year's achievement of the export trading in the growth and transformation plan (GTP2) of the country. The evaluation result indicates the lower performance of the export sector as compared to its targets. In alleviating such deficiencies, increasing product and productivity of the agriculture and manufacturing sector, with an exceptional focus on export-oriented products and services, are identified as economic activities that should be given especial concern. The committee identifies areas that need special attention: (a) to limit government's participation in the manufacturing and service sectors of the economy to transfer the scarce resources from owned by inefficient public sector enterprises to efficient private entrepreneurs and to re-deploy such resources in higher prioritize and efficient private enterprises and to meet poverty reduction programs in a given economy, (b) increase foreign exchange, (c) growing the government's capacity in terms of generating more income from tax, (d) to simplify problems regarding the costs of living, (e) reducing unemployment, (f) bringing efficiency and competition in the economy, (g) to control inflation (h) alleviating the problem of good governance. In this regard, to fasten the existing economic growth with a better export achievement that can be compared with the current economic growth, the government has justified and decided the need for economic reforms in the country. The following benefits, among others, would be acquired from this reform: To mitigate the severe internal and external imbalance currently facing the country, to bring inclusive growth-Via allowing local investors to share in the country's mega projects in order maintain sustainable economic growth in the country, to participate the Diaspora-via allowing those Ethiopians and Ethiopian citizens to play their part in the process of developing their county's economy and to acquire technology and human skills-via foreign investors having better capital, technology, and skills. In line with the abovementioned reasons, in general, the committee has passed the following decision: Those public-owned manufacturing or service giving enterprises, currently in production or on establishments, such as railway, sugar manufacturing, industry parks, hotel, and other different manufacturing enterprises, fully or partially, should be privatized via share sales. Also, the committee has decided to privatize, via share sales and with the government having the majority of the shares, such relatively large and highly profitable public companies in the country, as Ethiopian airlines, Ethiopian telecom, Ethiopian electric power corporation, and Ethiopian shipping and logistics enterprise. According to the federal democratic republic of Ethiopia executive committee, such big and highly profitable public companies are intended to be sold, via share sales, to both local and foreign investors. Regarding the practical execution of such decision, the committee has announced that its practical execution will be performed following the already existing developmental state policy by maintaining the fast and bearable economic growth, and by keeping all other maintainable benefits to Ethiopia. Thus, for its practice, the committee has indicated as if the issue is to be detailed and supplemented with professional views with an intense ethical manner.

Coming to the current situation of Ethiopia, privatization of the four large and highly profitable public companies; Ethiopian Airlines, Ethiopian telecom, Ethiopian electric power corporation, and Ethiopian shipping and logistics enterprise, to local and foreign investors, and other public companies; railway, sugar factories, Hotel industries, and other manufacturing companies, solely to indigenous investors, was declared with the justifications mentioned here above in the subsequent paragraphs.

Thus, in its entirety, this paper attempts to discuss various issues regarding privatization in Ethiopia. First, it tries to see the main objectives of privatization, in general, and in Ethiopia in particular. Second, it reviews the general theoretical frameworks for and debates on privatization. Third, Challenges and Prospects have been assessed together with Countries Experiences on Privatization. Fifth, the Institutional Structure of Privatization and finally directs ways Forward for the current privatization practices in Ethiopia.

\section{Objectives of Privatization}

Privatization is becoming a crucial component of structural reform programs for developed and developing economies aiming at achieving greater microeconomic efficiency and enhance economic growth, and as well as reduce public sector borrowing requirements through the elimination of unnecessary subsidies (Sheshinski \& López-calva, 2003). Microeconomic philosophy thoughts that incentive and contracting problems create inefficiencies as a result of public ownership, assumed that managers of nationalized enterprises chase objectives that differ from those of private firms (political view) and offsite monitoring (management view). Besides, the managers' objectives slanted and the budget constraints they face are also softened. The soft-budget constraint arises from the fact that bankruptcy is not a trustworthy threat to public managers, for it is in the central 
government's own interest to secure or bail them out in case of financial distress.

Generally, the literature on privatization has been growing rapidly since it is becoming an increasingly important matter in governments' policy (Marsh, 1991). Broadly, two main views have been projected by theoretical studies; normative and altruistic. The former states that privatization is essential to diminish waste, lift up economic efficiency and multiply the activities of the private sector by means of increasing both domestic and foreign investment. In this normative view, the main driving force for privatization being the eradication of the soft budget constraints. That is, the softening of the budget constraint occurs when the strict relationship between expenditure and earnings has been relaxed because an excess of expenditures over earnings will be paid by some other institution typically by the state. That makes public firms a major cause of economic inequality since they encourage waste and obstruct the flow of services (Harsch, 2000; Kornai, 2000). In addition, this theory presumes substantial governments and politicians. The latter, altruistic theory, views the issue mainly from the perspective of maximizing aggregate welfare; keen to dispose of an optional system for one where market forces determine performance. These authors forward their views that normative view provides long term justification than the welfare views due to two reasons: on the one hand, it takes much time to realize the benefits the welfare benefits of privatization, and on the other hand, the normative view gives long-standing grounds for public sector divestments. Possibly, the most over-riding quarrel for privatization is that it will lead to greater efficiency in resource use on account of competition. It is important to note that this argument is based on the assumption of competition. Privatization without competition does not necessarily involve superior efficiency, because it may simply mean the replacement of public monopolies by private ones. A long time ago, privatization policies have been implemented across the world and the economic literature dedicated to the issue of privatization has been persistently increasing (Chole, 1993).

According to the common wisdom, as indicated by Cavaliere et al. (2006), mainly countries' governments implement privatization policies to achieve the following three goals: (i) to diminish national budget deficits and the stock of national debt (contributes in reduction of government expenditure due to subsidies, helps to increase tax revenue. However, that privatization revenues do not lead to an increase in government spending, because they are considered a once and for all yield and are reserved to reduce the stock of nation-wide debt); (ii) to foster financial markets development (contribute to the growth of stock market capitalization and trading all over the world); (iii) to increase efficiency (controversially, as per the hypothesis of conventional wisdom, privatization policies contribute to increase efficiency provided the transfer of an enormous amount of resources from government control to market allocation. However, the threat is that such a popular belief may be due to ideological faith in the virtues of economic liberalism rather than to a proper assessment of the impact of the firm's ownership on productive and allocative efficiency). Furthermore, Cavaliere et al. (2006) argue that the theoretical results regarding the association ship between privatization and efficiency do not lead to any decisive conclusion; Privatization may increase productive efficiency when restructuring takes place whereas its effects on allocative efficiency still remain uncertain.

Though it is domineering from the macroeconomic perspective, it could be mistaken to evaluate the relevance of countries' privatization program by looking at the revenue to be generated for the government. The fundamental component of set of objectives of privatization programs is the enhancement of microeconomic efficiency. Generally, Sheshinski \& López-calva (2003) justifies four specific objectives: (i) to achieve higher allocative and productive efficiency; (ii) to strengthen the role of the private sector in the economy; and (iii) to improve the public sector's financial health and to free resources for allocation in other important areas of government activity (usually related to social policy). As to them, the first two sets of objectives have a normative rationale and relate to the microeconomic perspective, while the latter is related to public sector finance and are the reduction of borrowing requirements and the potential reallocation of expenditure towards social policy areas.

\subsection{Main objectives of privatization in Ethiopia What is privatization?}

The concept of privatization is fuzzy which evoke sharp political reactions; it embraces a vast range of ideas and policies which varies from extremely reasonable to the broadly impractical, it has clear cut political origins and objectives although its meaning is diverse and at times not clear, it emerges from the countermovement against government growth and corresponds to today's most grave conservative endeavour to formulate a positive alternative, its plans don't aim merely to return services to their original location in the private globe; some of the privatization proposals look for creating new market relations and swear results as comparable or superior to public programs. Therefore, it is a mistake to define and dismiss the movement as just a replay of the traditional opposition to state intervention and expenditure (Starr, 2018). Privatization means the transfer of public assets to private ownership (Chole, 1993). Privatization, as one of the tough issues in the process of economic reforms, has got different definitions in the literature. According to Young (1991), the term privatization can be defined both narrowly and broadly: In a narrow sense, privatization refers to a shift of production activities or services being undertaken by the public sector to private ownership or control, and broadly it can be defined as a process by 
which the state's role within the economy is restricted while at the same time the scope for the operation of private capital is deliberately extended. Also, others like Simmons \& Simmons LLP (2018) define privatization as a way of transfer, through sale, of an enterprise or its units or assets or government shareholdings in a share company to private ownership; privatization refers more broadly to a general trend in which the private sector takes over assets and functions from the public sector, thus reducing direct government control (Deneke, 2001). Besides, the dictionary of economics and business defined privatization in simple terms as the sale of public corporations and assets to the private sector. Since privatization entails ownership transfer from public to private sector and the changes in income flows between groups, it has thus important socioeconomic implications in a given economy; privatization and public sector reforms have become more demanding than reforms on exchange rate and prices, (stroke of the pen) measures, to bring macroeconomic stability. Donors and multilateral agencies made Privatization a crucial conditionality. Most African countries undertake privatization not primarily due to ideological or economic convictions; somewhat, they did it to moderate patron over domestic reform commitment (Kayizzi-Mugerwa \& Stev, 2002).

Generally, from the definition given to privatization, one can infer two issues; one transfer of full public ownership and direct control to the private sector, and two transfers of partial public ownerships but direct control.

\section{Theoretical Frameworks For Privatization}

\subsection{The Front Theoretical Arguments For Privatization}

The logic that privatization leads to greater efficiency lies on empirical and theoretical arguments. According to the fundamental privatization theorem, any government targeting to reach efficiency and equity ends can always delegate production decisions to private firms via auction systems, as long as some ideal assumptions concerning information, risk-aversion and collusion are respected. The would-be producers (agents) must be risk-neutral and characterized by symmetric beliefs about the least-cost production technology Cavaliere et al. (2006), however, nationalization is neither desirable nor necessary, as governments can use politically independent regulatory agencies. They further conclude that the theoretical literature regarding privatization and efficiency relies on indifference theorems, appealing the ownership structure is neutral, thereby justifying privatization policies on the grounds of efficiency when observing neutrality failures.

Empirically, there is immense evidence to demonstrate that public enterprises have performed miserably compared to private enterprises, especially in developing countries (Deneke, 2001; Odukoya, 2007; Sheshinski \& López-calva, 2003; Starr, 2018; Waigama, 2008; Wallace, 2016). However, this doesn't mean that all public enterprises are inefficient, as exceptions but not rules, there are highly viable public enterprises in several cases. It argued that privatization involves the appropriation and expropriation of the national surplus created by labour, and represented in the social wealth of the public enterprises being put up for sale. Subsequently, vital to the problem of privatization is the issues of power, the authoritative allocation of resources, and the decentralization of the role of the state in development (Odukoya, 2007). In this regard Odukoya, (2007) argues that privatization goes beyond the mere transfer or ownership change of state-owned enterprises, it involves the redefinition of class boundaries, sharpens class disagreements and antagonism by biasing or skewing resources and power in favour of private capitalist claimants, as well as the dominance of neo-liberal ideology. He further argued that market-based corporate governance enforced by privatization tends to weaken both the trade and labour unions, as well as deprives the citizenry. Then, since private capitalist claimants constitute the leading lights of the civil society, as a result, the civil society in turn stands the risk of being powerless and weakened, and democracy endangered.

On the other hand Sheshinski \& López-calva, (2003) argue and provoke that privatization increases profitability and efficiency in both competitive and monopolistic sectors, and further justified as if full privatization has a greater impact than partial privatization and monopolistic sectors show an increase in profitability that is above the component explained by increases in productivity, which reflects their market power. From the macroeconomic perspective, no conclusive evidence can be drawn, but the trends are favourable (Sheshinski \& López-calva, 2003)

Theoretical arguments for privatization have continued to define the framework of privatization program in to three main theories: the principal-agent theory, the theory of public choice and the theory of competitive forces (Chole, 1993). Alternatively, the residual claimant or property right theory; the public choice theory and the dispersed knowledge theory (Odukoya, 2007).

The neo-liberal theory blames the public sector for the economic distress of the country by emphasizing the replacement of the public sector for the private sector in the process of economic development. The argument of this theory is that the public sector is expected to play supportive roles in the process of economic development. This paradigm shift has been levelled as Governance Led Development Theory (GLDT) and made its central theme good governance, which provides the lead in the development process (Ogwezzy \& Bello, 2013). Additionally, Tandon (1995) argues in support of the neo-classical theory to bring the right incentives to owners and thereby encourage efficiency in a given economy. He suggested that private owners have the right incentives to promote efficiency; government owners mismanage principal-agent issues to a larger extent than private ones. However, 
eventually, He preaches caution about the matter of productivity about the competitive nature of the market; in a competitive market, there exist means that could allow public enterprises to operate as efficiently as its private enterprises, but if a market is monopolized, privatization by itself will not guarantee efficiency.

With respect to the principal-agent or the residual claim or property right theory, changes in the allocation of property rights change the structure of incentives that decision-makers face in the firm and hence lead to changes in both managerial behaviour and company performance. The vital point here is that managers of private enterprises have the incentive to maximize efficiency but those of public enterprises (Chole, 1993). This then involves the need for incentives as a basis of facilitating monitoring by managers. It is the absence of monitoring incentives, like profit in the case of the private business owners, for public enterprises managers that account for the inferiority on the efficiency scale of public enterprises when compared with private businesses (Odukoya, 2007; Chole, 2018; Kivisto, 2007). The initial contributions to the theoretical literature on privatization and efficiency can be considered as extensions of the Principal-agent theory to ownership issues (Cavaliere et al., 2006). The benefits of privatization may either derive from the constraints it places on malevolent agents or to the impossibility of commitment by a benevolent government because of incomplete contracts (Cavaliere et al., 2006; Martimort, 2005). Empirically (Dharwadkar, George, \& Brandes, 2000) argue that the ineffectiveness of numerous privatized firms within emerging economies underscores the importance of agency theory issues and their impact on the privatization performance relationship. They argue that weak governance and limited protection of minority shareholders intensify traditional principal-agent problems (perquisite consumption and entrenchment) and create unique agency problems (expropriation). They suggest that post privatization performance can be enhanced by using appropriate ownership, management, and corporate structures that mitigate agency problems in the context of weak governance.

Furthermore, there are two perspectives under the principal-agency view for the existence of poor motivations for efficiency; the managerial view and the political view. The former claims as if monitoring is poor in stateowned enterprises and hence the incentives for efficiency are low-powered, i.e. the impossibility of writing complete contracts with the private owner plays a fundamental role in explaining why ownership indeed matters. The latter claims as if political interference distorts the objective and constraints faced by public managers; this view relies heavily on the "benevolence" of the government, in the sense that it always has the right social welfare function as an objective to be maximized (Sheshinski \& López-calva, 2003).

The public choice theory, also known as the policy choice theory, states that, the performance of public enterprises are a function of the combined actions of the general public, politicians, bureaucrats and managers, each group seeking to maximize their own particular objectives (which may not coincide with efficiency) and none having identical information, with the end result being the internal inefficiency of the firm (Andic, 1992 cited in Chole, 1993). However, in a competitive environment, there is almost uniform access to information, contributing to greater efficiency. This theory perceives state-owned enterprises as the paradise of corruption, archaic accumulation and political patronage by both bureaucrats and political officeholders. Dharwadkar et al., 2000; Meheret, n.d.; Odukoya, 2007; Sheshinski \& López-calva, 2003, argue that politicians used public or state-owned enterprises chase their own political objectives for example via giving redundant jobs at these enterprises to their supporters. They suggest two states of affairs for privatization under this condition: when politicians who benefit from low taxes win over those who benefit from subsidizing supporters and when conservative governments, favoured by taxpayers, replace leftist governments (those who are on the left-wing of the political spectrum), favoured by public employees. The fear of collusion/conspiracy between politicians and civil servants to appropriate public goods via state-owned enterprises is also very popular, i.e. political incentives affect the likelihood to privatise. 


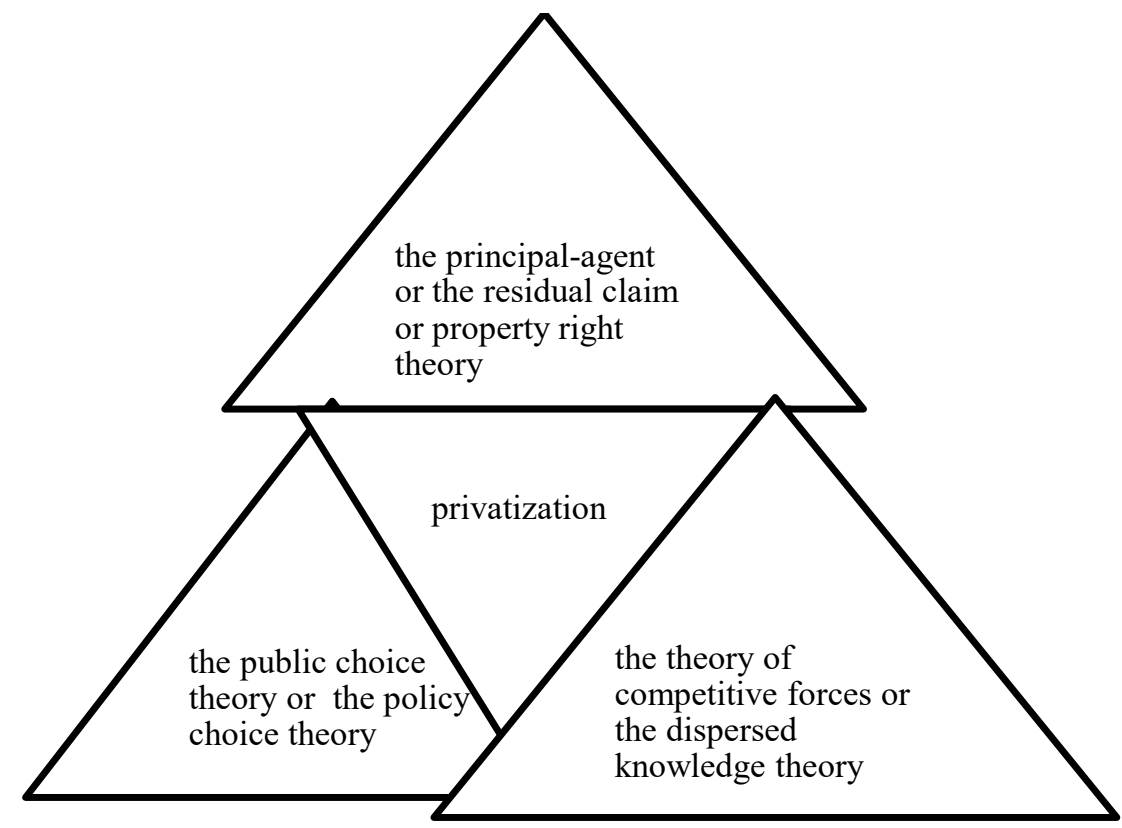

Figure 1: privatization theoretical framework

Furthermore, according to Draki (2007) theories such as the public choice theory, the theory of economic constitution and the theory of collective action argues that transition from one economic system into another, for example transition from collectivistic, socialistic system into capitalism and free market economy with dominant private property, will not happen through isolated changes of only few economic institutions, no matter how deep that changes would be. In other words privatization cannot give results if it's not followed by comprehensive change of economic system, because privatized companies wouldn't be able to operate in old environment.

In the light of the arguments here above, others such as (Wright, 1993; Jonathan \& Enrico, 1995) argue as bellow: Public choice theory provides a logical framework on which the nature and timing of the economic transition process can better be understood; i.e. Public choice theory claims as if political decisions are made by politicians performing rationally in keeping their own self-interest and they will form political alliance when the potential benefits from legislative preference exceed the costs of organizing and supporting any given piece of legislation. They wrap up that public choice theory precisely predicts the shape of the economic transition process from one economic system to the other and that the public choice model of transition has a normative value. On the other hand, there is an equal agreement among theorists that the method of achieving this transition is through; current account convertibility (firstly) and capital account convertibility (finally). Afterward, the real exchange rate (may be weak or strong) is used to measure the relative prices between tradable and non-tradable commodities in a given economy; in a country with full current account convertibility, the price of tradable goods and services will raise as a result of a weak real exchange rate. Conversely, if the real exchange rate for the same is strong, the price of non-tradable goods and services will be higher comparatively than the price of tradable commodities. Hence, producers will incline to produce more of non-tradable goods and services than tradable. As a result, there will be the shortage of tradable commodities to export and the country will have a foreign trade deficit. Further, due to the higher relative price of such non-tradable commodities, consumers will be forced to buy fewer domestically produced non-tradable and more imports. Finally, this demand shift will result in an excess supply of non-tradable, which the world market will not absorb, as a result of the decrease in the domestic currency deflationary pressure will result and unemployment will increase as the production of non-tradable commodities diminishes and the production of exports contracts (Wright, 1993; Jonathan \& Enrico, 1995).

According to the competitive forces or the dispersed knowledge theory, the existence of competitive forces in the market plays a vital role in terms of breaking down of the monopoly of information, allowing freedom of entry into markets, and creating incentives for the foreword of innovation. The central point here, in other words, is that it acts as a discipline for lethargic managers and effectively regulates company behaviour; subsequently it is at the heart of much debate on privatization policy (Andic 1992 cited in Chole, 1993). Some theorists call the competitive force theory as the dispersed knowledge theory and argue that that competition plays an important role in the generation of information necessary for effective coordination (Dharwadkar et al., 2000; Odukoya, 2007; Yarrow \& College, 1998), product market competition is not an argument for private ownership per se, an effective market competition in general will generate the same information regardless of who owns the enterprise concerned.

\subsection{Other organizational theories}

Alternatively (Carter, 2013) has seen privatization from a multi-theory perspective as organizational theories and 
answer two interrelated questions: (1) Why does a country decide to undergo privatization in some industries but not others; and (2) Why do some countries enjoy success while others experience failures from privatization? In doing so, he reviewed the seven organizational theories such as system theory, contingency theory, real option philosophy, institutional theory, agency theory, resource-based views and transaction cost economics. He put forward his views from each theory in terms of key premise, key insights for privatization and propositions (hypotheses) for future pragmatic research. For instance, the essential premise indicated under system theory states that Public and private organizations are viewed as components of a country's integrated political, social, and economic system. Similarly, there is no universal or one best way to privatize (argument for contingency theory); areal option is the right choice, but not the obligation, to undertake privatization in an uncertain environment (real option theory); Social structures, including rules, norms, culture and values, guide people's social behaviours (institutional theory); a country should use monitoring and control mechanisms to manage principal-agent relationships(agency theory); Critical assets are sources that a country should not privatize (resource-based view); a country should make privatization decisions that improve its economic efficiency and society as a whole (transaction cost economics). All these theories have their own prepositions in the literature for empirical investigation (see (Carter, 2013), not the scope of this paper.

\section{Challenges and Prospects}

Following the adoption of privatization policy, there are several tricky problems that need to be resolved. Mainly, substantial problems may arise in relation to: deciding which enterprises to privatize; what privatization modalities to use (discussed in section 3 above); how fast to privatize; and how to value the assets of the enterprises to be privatized. Regarding problems in answering which firm to privatize, the countries' governments are rarely willing to sale highly profitable enterprises and usually buyers have no to acquire such an enterprise, especially those that are heavily in debt or debt-ridden. However, the usual and common insistence of government is to privatize only loss-making public enterprises, which is not found justifiable for the simple justification that it imposes a negative image to the privatization exercise. On the other hand, big enterprises may not get buyers due to the reason that the cost of buying such enterprise may be exorbitant to the private sector, even it may create a risk of ownership concentration, and thereby, the process may end by substituting public monopolies by private once.

As far as the speed of privatization, a more troublesome problem is how fast to proceed with the privatization implementation. Too much speed may prove disruptive while moving at a snap pace may deprive the whole exercise of credibility. It is for this reason that a carefully worked out plan for sequencing actions is indispensable, justifies the necessity to create an institutional mechanism for dealing with matters of privatization. An even bigger problem in this context is whether privatization should precede or follow other measures for economic reform, including liberalization of prices, exchange rate reform, among others. The other problem related to privatization is the complexity of asset valuation. Given several methods of different levels of sophistication for doing this, simplicity and transparency would be highly desirable attributes to resolve these concerns; on one hand is to ensure that public property is not undersold and on the other hand, asset values should not be set so high that potential buyers would be driven away (Chole, 1993).

\section{Debates on Privatization}

The issue of privatization in most African countries is being challenged by arguments from various groups of politicians, bureaucrats and other stakeholders including the issue of privatization by donors and multinationals. It is during the era of the 1960s and 1970s that most African government has got not only the real commencement of political independence but also control their economies for the first time. Given the justification of state ownership on the ground of scale economies, employment and regional balance, most of SOEs have been operating very poorly in terms of efficiency, capacity utilization, and mostly depend on government subsidies.

The debate on privatization to either indigenous, foreign ethnic or both owners is continuing in Africa, the current issue of Ethiopia. Apart from small enterprises, African governments have not been transferring the ownership title from SOEs to the private owners, no trial to adopt the voucher type of privatization as eastern Europe, as mentioned before, rather they have been practicing the stock exchange-type of privatization that remained small and fragile till the current time. The debate on foreignization, referred by local opinions as loss of resource to abroad and loss of independence, has presently got the great concern in Ethiopia. The debate on the matter is from the ground that the government of Ethiopia, at present, is suffering from political instability, inefficient ongoing giant public projects (such as the renaissance dam of Ethiopia and the various power and sugar factory projects, among others), sever foreign exchange shortage and trade deficient, and enormous debt burden to the extent of 1.4 trillion ETB (out of which \$26 billion from overseas lenders and the rest from local ones), the only reason to decide on privatization of SOEs, such as Ethiopian Airlines and Ethiopian telecommunication, among others, is just to resolve primarily such foreign exchange problems and then the country's debt burden. As a result, such selling of large companies to foreign companies and individuals is reason enough to claim that Ethiopia is 'being sold to foreigners'. Besides, they argued that the local capitalists that spread this view are not in 
a position to purchase the assets on sale and the government has no money to lend them. On the other hand, the debate is on the fear that even though the local capitalists have allowed participating in owning these companies, they are not competitive enough and cannot share the market equitably. As a result, the risk of consolidating the state-owned enterprises in the hand of a few oligarchs will be realized. This due to the strong justification that, for more than the past two decades, the ruling government of Ethiopia was feat deliberately to consolidate the country's economy in the hands of some politically affiliated capitalists who are the supporter of the ruling government, and at the same time those who are ethnically originated from the ruling party since 1991 to 2018. Besides, most of those politically affiliated capitalists in those years have been transferred their money from local banks to aboard. Thus, taking into consideration such facts on the ground apart from the theoretical debate of privatization, they argue that as if this is not the right time to privatize such companies either to foreign or local capitalists, instead the government should first focus on how to collect those monies deposited in foreign banks by some oligarchies, focus on political stability and build trust, among others.

The other area of argument in Ethiopia is who should determine the values of such SOEs, the speed, extent, and depth of privatization. It is well known that donor communities and multilateral agencies such as IMF and World Bank have vast involvement in the implementation of privatization in many African countries in terms of setting up and financing of the institutional structure of privatization via ensuring the process with the real situations on the ground. At the earlier stage of privatization, such donors have been exerting much more influence than local actors. The other controversy to date is on the issue of valuation of businesses, the use of the proceeds, and to a greater extent the public tends to assume that at the time of implementation such enterprises may not operate which results in an opportunity cost that can worth more than the proceeds that can be acquired via privatization. As a result, these could raise public doubt, leads to collusion (particularly when assets were sold cheaply to 'foreigners') (Steve, 2002). All of the aforementioned scenarios characterize the Ethiopian context nowadays.

In practice, privatization in Ethiopia can be seen from two phases; the first phase before the establishment of the Ethiopian privatization agency in 1994 (i.e., 1991-1994) and the second phase after the establishment of the agency (i.e., after 1999), meanwhile some collapse. The second phase has been mentioned in the literature from 1999-2004. Regardless of the various causes for privatization such as pressure from international donors (Deneke, 2001; Nellis, n.d.), a huge budget deficit as a result of bulky public debt and external debt, and humble performance of SOEs in terms of production and profitability, poor growth of SOEs (Hansson, 2004; Selvam, 2007), among others, around 1,198 SOEs have been privatized in Ethiopia since 1994 up to 2010 (Ismail, 2018). On the other hand, empirical studies on the performance of SOEs after privatization lack conclusive results: for example, Selvam, (2008) suggested that in the year 1995-2004, the production level has been decreased by $14.21 \%$ in the post privatization period, modest after-tax profits in those periods and some improvements in terms of technical efficiency has been improved. On the contrary Gebeyuhu (2000) finds that technical efficiency was not higher in privatized firms, and no positive shifts in management philosophy or training were originate. On the other hand, Wodajo \& Senbet (2017) argued as if there was no productivity improvement in the manufacturing sector from 1994 to 2010, but some improvements on capacity utilization have been observed after privatization. In the year 2003 privatization was slowed down due to the re-nationalization of some firms as a result of fear of corruption (Wodajo \& Senbet, 2017), privatized enterprises were suffering from lack of raw materials, completion from imports, economic and political uncertainties (Deneke, 2001). Wondwosen, 2009; Wodajo \& Senbet, 2017, argued that two large business conglomerates; the Endowment Fund for Rehabilitation of Tigray (EFFORT), which is an endowment fund owned by the EPDRF and the MIDROC Ethiopia Investment Group, owned by Sheik Mohamed al-Amoudi, were the main exceptional beneficiaries of the privatization program in Ethiopia that is due to the preferential treatments from the government to operate as a duopoly (a situation in which these two enterprises dominate the market for a commodity or service) that undermines competiveness. This is one of the reasons to justify the risk of consolidating the state-owned enterprises in the hand of few oligarchs.

\section{Countries Experiences on Privatization}

The scale and experience of privatization in British are superior to elsewhere and often view as a blueprint for other countries (Veljanovski, 1987). There are various privatization developments. Wiltshire \& Savas, 1987; Young, 1986. Young, 1986, have discussed the different forms of the British privatization experience, as organized into seven forms: first, special asset sale-involve denationalization, e.g., British Gas, British Airways and British Telecom, the sale of public sector companies previously bought by the government, the sale of government holdings in private companies; second, deregulation or relaxing state monopolies to bring competition, e.g., the British Bus industry; third, contracting out work previously done by direct labour in local government, e.g., the civil service; fourth, the service provision to the public by the private sector, e.g., such as the experience of British; the private sector homes for disturbed adolescents, the mentally ill and handicapped and nursing homes for the elderly; fifth, allowing the private sector to invest in public projects in deprived areas and extending private sector practices into the public sector (i.e., via the creation of special units within the public sector organization to 
maintain a better commercial return on assets); sixth, reducing subsidies and increasing charges, e.g., concerning to the welfare services (Young, 1986). Seventh, an important element of privatization is the sale of council houses that greatly reduced public sector housing provision and the scope of the public sector for housing.

To discuss the privatization experience of the range of African countries, it is better to trace the issue back to the 'socialist' revolutions of the 1960s and 1970s. It was during this time that the bulk of state-owned enterprises (SOEs) were inherited from the colonial governments at independence. Thus, countries, specifically sub-Saharan Africa countries such as Côte d'Ivoire, Ghana, Kenya, Mozambique, Tanzania, Uganda, and Zambia, experience and performance of privatization could be seen from the three stages of privatization process as an initial stage (initiation), consolidation and fully-fledged privatization.

Provided the various triggering factors for privatization, in most African countries privatization was initiated by the pressure from the donor community, and when it is implemented, domestic factors began to play. Consequently; some privatization can be relatively smooth, some others fail in controversy, and the rest could be drawn out, and in some cases, the government will be forced to postpone or completely cancel the program. Hence, one can notice that the factors causing privatization and the time when to privatize are the main ones, especially to privatize SOEs in those countries in which Ethiopia belongs. So far, the Ethiopian economic policy focus was exclusively on macroeconomic stabilization; this is conventionally known as the "first-generation policy; whereas Privatization and public sector reforms termed as 'the second generation policy' (Appiah-Kubi 2001). Currently, the Ethiopian government has decided to privatize some of the most strategic state-owned enterprises mentioned so far, given the various controversies from politicians, bureaucrats, and other stakeholders on the causal factors and the time when to begin privatization from different groups in and outside the country.

In most countries, nationalization was completed after prolonged negotiations with incumbent owners via giving sufficient compensation for former private owners, such as the case of Tanzania, Mozambique, and Zambia. This was because in many of them nationalization was equated with indigenization, with businesses belonging to foreign-born ethnic minorities mainly targeted for take-over However, unlike in Mozambique and Tanzania, the smaller firms were acquired by indigenous Ugandans that were close to the political leadership, only the larger firms were taken over by the state in the early 1970s. In most cases, governments own basic businesses in several areas with the assumption to create economic dynamism, ensure regional balance in economic development, scale economies, and employment creation, particularly in Africa, state ownership became quite entrenched. For instance, in Kenya and Côte d'Ivoire (a country generally considered capitalist), the state still holds extensive business holdings in most areas of the economy including multinational corporations and has not excluded private individuals from holding large stakes in the economy, although there have been complaints about asymmetrical competition (Steve, 2002).

\section{Practical experience on privatization: transition and developing countries}

Privatization is not a uniform process across countries, mainly due to their political nature and the various approaches to privatize. Among the methods that African countries experienced to privatize companies were a direct sale, usually via tender or direct negotiation, public offer (via the stock exchange), joint venture, lease, for example, of hotels in national parks, sale of assets, liquidation and management buyouts. The direct sale, as the most common method of privatization, has been applied 100\%, fore ample, by Mozambique, Ghana (89\%), Zambia (87\%), Uganda (86\%), among others. The well-developed stock exchange methods have been used by Kenya (35\%, the sale of Kenyan Airways was partly undertaken via the stock exchange as well as that of a commercial bank), Ghana and Nigeria ( $72 \%$ of its privatization via the stock exchange, although generally, its privatization rate has been slow, to be characterized as being in the 'breaking resistance' phase).

Table 1: Country's' Practical experience on privatization

\begin{tabular}{|c|c|c|c|c|c|c|c|}
\hline \multirow[t]{2}{*}{ Countries } & \multicolumn{4}{|c|}{ Privatization methods } & \multirow[b]{2}{*}{ Lease } & \multirow[b]{2}{*}{$\begin{array}{l}\text { Management } \\
\text { buyouts }\end{array}$} & \multirow[b]{2}{*}{$\begin{array}{l}\text { Return of } \\
\text { assets and pre- } \\
\text { emptive rights }\end{array}$} \\
\hline & $\begin{array}{l}\text { Direct } \\
\text { sale }\end{array}$ & $\begin{array}{l}\text { Stock } \\
\text { exchange }\end{array}$ & $\begin{array}{l}\text { Joint } \\
\text { venture }\end{array}$ & Liquidation & & & \\
\hline Kenya & $>40 \%$ & $>35 \%$ & & $>20 \%$ & & & \\
\hline Tanzania & $>50 \%$ & Practiced & $>20 \%$ & Practiced & Practiced & & \\
\hline Nigeria & $72 \%$ & $28 \%$ & & & & & \\
\hline Uganda & $86 \%$ & Practiced & Practiced & & & & Practiced \\
\hline Ghana & $>89 \%$ & Practiced & Practiced & Practiced & & & \\
\hline Mozambique & $100 \%$ & & & & & & \\
\hline Côte d'Ivoire & $76 \%$ & $24 \%$ & & & & & \\
\hline Zambia & $87 \%$ & & & & & Practiced & Practiced \\
\hline
\end{tabular}

In views of practical experience in transition countries, several studies have been conducted to see the effect of privatization of a firm's performance (see Djankov and Murrell, 2002; Sabirianova, Svejnar, and Terrell, 2012). 
The convincing evidence was that privatization to foreign owners and foreign direct investment yields a positive effect, though not in every circumstance. To this end, the nature and characteristics of the new private owners, and institutional and business environment in which privatization takes place are found the two influential factors determining whether privatization acts to enhance company performance virtually in all transition economies.

As far as privatization experience in developing countries, sectorial empirical evidence suggests that mostly the performance of Banks improved pot-privatization, efficiency gains tend to limit in case of utility sectors such as electricity and water, and finally, the impact of privatization on efficiency and outreach in communications sector varies per region (Clarke et al., 2005; Boubakri et al., 2005; Beck, Cull and Afeikhena, 2005). Besides, it is found in those empirical studies that Privatization is more beneficial when it is full rather than partial, and few benefits are associated with privatization alone, and it alone works only when coupled with operative and independent regulation and increases in a rivalry (Wallsten, 2001). Over all, privatization gains in terms of economic achievement and principles are found limited, while introducing rivalry is more effective to stimulate performance. Thus, it is recommended that the assessment of the consequence of privatization on achievement in terms of efficiency, profitability and distribution (through its effect on ownership, employment, prices, access, and fiscal consequences, and its impact on gender), among other things, should be dynamic, taking into thought the point on the pathway when one measure the end result. It is crucial for Sub-Saharan countries to have extended and dynamic private sector, efficient and effective infrastructure, and an expanded local and foreign investment. Privatization is one of the ways to address these gaps, though African countries are generally known as slow and reluctant privatizers; a maximum share of industrial or manufacturing and mostly infrastructures are found state-owned. Given the existing public argument towards privatization and the pervasive institutional weakness, the long-run resolution is the creation and reinforcement of the institutions that support and guide suitable market operations (Nellis, 2008).

\section{The Institutional Structure of Privatization}

In most African countries, the Legal and institutional structures for privatization has established in the early 1990s with the help of the donor community; for example, Ethiopia \& Togo 1994, Ghana, Uganda \& Guinea 1993, Kenya, Zambia \& Tanzania 1992, Mozambique (1989-1993). Concerning laws and policy decelerations of Ethiopia on the matter, Ethiopian Privatization Agency established by Proclamation No.87/1994, latter the board of Trustees of Privatized Public Enterprises was established by Proclamation No. 17/1996. Regarding the board composition of the privatization agency, the Agency has five permanent members designated by the government. When a company is in the process of privatization, the chairman of its board and the worker representative on the board would participate in the Agency's deliberations as non-voting members.

Apart from the domestic opposition on privatization, the very serious sabotage that delayed the privatization process in many African countries is the lack of institutional structure for privatization (Draki, 2007; Tsegaw, 2016). It took a prolonged time governments to nullify the state monopolies and set out the legal framework (including revisions of laws covering areas such as taxation, bankruptcy, land ownership, competition, and regulation) to implement privatization. Although the rules, ordinances, and related documentation shares mutual features across African countries (such as the case in Ethiopia, Ghana, Guinea, Mozambique, Tanzania, Togo, Uganda, and Zambia), the documents, however, reveal some slight differences in terms of reflecting their respective political concerns.

As mentioned so far, the government of Ethiopia has newly created the Ethiopian in 1994 to carry out the privatization process in an orderly and efficient manner. However, the level of autonomies given to such agencies varied across countries in Africa; for example, the Ethiopian privatization agency was established to be autonomous in terms of its legal personalities, however, as mentioned here above, all the five permanent board members were nominated by the government and were accountable to the prime minster in all matters. Here, the chairman of the board and worker representative was allowed to represent the enterprises while the agency negotiates for sale. In comparison, to make the long history short, the approach for privatization in those African countries mentioned here above was centralized; in Ghana the purpose of the divestiture Implementation Committee was defined as 'to implement and execute all Government policies in respect of divesture programs; in Guinea the Minister of State Assets assumed authority over the privatization exercise, signing transfer documents on behalf of the government and supervising the work of the Privatization Committee, in Togo the minister in charge of public enterprises having the principal responsibility, in Kenyan and Tanzanian privatization legislation is light compared to other sub-Saharan African of the Republic of Kenya 1992 and Tanzania 1992, 1993), found more modest models contrast sharply with that of Mozambique. In many African countries, the authorities or ruling parties only decided to commence privatization after pressure from donors and the multilateral agencies, but Zambia's was unique in this regard, its privatization effort was part of the ruling Movement for Multiparty Democracy's (MMD) election manifesto (Draki, 2007; Ethiopian Agency, 2018; Ethiopian Studies, 2018; Tsegaw, 2016; Waigama, 2008). These authors concluded that the post of African governments was aware of the political implications and the conflicts of interest from various groups before and after the implementation 
of privatization. According to them, the response to such challenges much depends on the respective countries' politics, the extent of corruption and donor leverage (country's debt), and past ownership structure.

\section{Ways Forward}

On the whole, studies on developing countries, including sub-Saharan Africa, show that private ownership alone does not generate economic gains, which justifies the existence of several factors on which the successes of privatization depends on such as whether privatization is full rather than partial, the regulatory framework which, in turn, depends on the institutional and political environment, the characteristics of the new owners, i.e., foreign vs. local ownership, (Estrin and Pelletier, 2015). Besides, the success (or failure) of privatization will depend on such factors as Market structure and degree of contestability of the market, the potential for spill-overs, and the institutional and political context.

Any privatization decision and the process in each stage should target the aim of privatization in promoting efficiency, and productivity, enhancing sustainable economic growth, ensuring autonomy, transparency and accountability of the management of businesses. Mastery of inflation is paramount significant; in doing so, proper monetary discipline with publicly stated targets is essential for the rate of growth of the money supply. At the same time, a gradual reduction in the size of the Government's borrowing requirement is also vital in reducing further printing money to pay the debt without first earning more income to the economy. The state must reduce steadily the share of the nation's income to pay its debt burdens. Besides, substantial savings will be yielded via the reduction of waste, bureaucracy, and over government, among others. Further, the government should cut income tax at all levels to reward hard work, responsibility and success (Jackson, 1985).

Though Privatization is thought to improve overall economic efficiency, hence enhancing general welfare, it is found arguable. On the one hand, any denationalization program should be designed to seek Pareto improvements, meaning that employees, consumers, government, and new owners will be better off, or at least no worse due to policy implementation (Vogel sang 1995). In this regard, privatization policies share at least four main objectives summarised by López-Calva(1998:6): (i) to achieve higher allocative and productive efficiency; (ii) to strengthen the role of the private sector; (iii) to improve the public sector's financial health, and; (iv) to free resources for allocation in other areas of government activity. Therefore, privatization should not be assessed only in terms of revenue raised by a government but also by the impact in microeconomic efficiency. Privatization in this sense is targeted to improve and broaden the range of services with better quality and lower prices.

On the other hand, there are arguments that claim that privatization would reduce services available and would induce an increase in prices. Welfare would be affected due to profit-maximizing firms looking for reliable and profitable customers instead of providing services for the whole society. According to Megginson (2000), 'the transfer of State-owned Enterprises (SOEs) to the private sector reorients their basic purpose away from the political goal and toward the economic objective' of maximizing profits. According to the latter, and in relation to the telecommunications industry, private providers would use their monopolistic position to exploit consumers and even the government.

Privatization has an important ideological content, namely, recognizing, that states are inefficient as providers of goods and services. Mostly, arguments in favour of denationalization are primarily based on productivity and efficiency analyses. Most of them support the view that every public activity should improve when divested (Nelson, 1994). Barnekov and Raffel (1990) claim that the "private sector is assumed to be inherently dynamic, and private institutions are thought to be intrinsically superior to public institutions'.

Ethiopian Privatization Agency Establishment Proclamation No.87/1994, the establishment of the Board of Trustees of Privatized Public Enterprises Proclamation No. 17/1996. The proclamations establishing the Privatization Agency as well as the Board of Trustees for Privatized Public Enterprises make no explicit mention of the need to favor Ethiopian nationals in the privatization process; this should be the prior concern of the government ahead of implementation. On the other hand, since the Ethiopian private sector is weak and fragile, there would be many gaps if the government withdraws from and leaves the economy to individual entrepreneurs. Thus, the role of the state should not be limited to the provision of definite economic and social infrastructures, but go as far as investing in areas where the private sector is unable to involve due to fear of long gestation periods, massive capital requirements and less profitable in purely financial terms. It should also maintain large ventures under its disposal, the privatization of which might cause social shocks in the process of restructuring. This could create additional production capacity and employment opportunities in the economy (Gebeyuhu, 2000).

The principal policy implication of this analysis for the Ethiopian government is that policy-makers who study Ethiopian privatization should quickly move beyond a simplistic emphasis on the pace of privatization (i.e., with donor leverage and multilateral agencies being an important determinant of the pace of implementation), to the neglect of both political and organizational factors that could create a stable foundation for economic fair share, not to concentrate enterprises to some politically affiliated oligarchies due to the current race-based politics of the country, and market relations among newly privatized Enterprises.

Privatization in the Ethiopian case will be successfully held towards attaining the stated objectives if the 
country follows the following procedures, among others:

i. A strong private sector will require an effective state

Because the private sector in many poor countries is highly dependent on the state. Besides, strong political will and firm commitment on the part of policy-makers is highly demanding for privatization to succeed.

ii. Cary out a detailed analysis of resources capability

- Investigation on the availability of money, specifically foreign exchange, which was not readily available in the banking system and the country as of today, should be a precondition for the country to assure the restructuring and rehabilitation process towards selling the enterprises and made ready for their better performance post-sale.

- There is no appropriate organization or legal framework to bear the complicated exercise of privatization and these should have to be created.

- Detailed analysis on the availability of skilled man power to undertake the various tasks that go with privatization, such as asset and business valuation, legal work, general management, etc., and this would have to be secured, either by importing foreign specialists or by training the presently available manpower.

\section{iii. Resource planning}

- As parts of the privatization framework, the acquisition and deployment of the necessary resources should be planned. In this regard, the government should plan to recruit key technical staff to provide the necessary institutional advisory services and logistical support and to assist individual SOEs to improve performance; should establish the agency and an organization structure to implement privatization; i.e., the SOE Reform and Divestiture Secretariat and the structure within; should borrow the required additional funds from the appropriate funding agencies to finance various aspects of the privatization programme.

\section{iv. The SWOT analysis}

- In the privatization strategy formulation, the country's main strengths and opportunities should be detailed, which comprised, among others, of the current political goodwill and stability; economic stability; the failure of most SOEs to perform up to the expectations Ethiopians; the presence of a strong culture of entrepreneurship and desire for private ownership; a relatively large educated middle-class, able and willing to be trained and acquire the many skills necessary to undertake privatization; a realistic trade union movement in the country.

- Such an analysis must also examine the weakness and threats to success, which may include several debtridden and non-performing SOEs that may not be attractive to potential buyers; shortage of private Ethiopian equity funds due to absence of capital market, low disposable income and savings, and limited liquidity in the undeveloped banking sector; shortage of foreign exchange in the economy to finance PE rehabilitation to improve value; many ownership and legal issues surrounding most PEs; lack of proper accounting records and standards such as IFRS, sparking the need to engage financial experts not readily available in the country, thereby delaying SOE preparation for sale.

\section{v. Study the impact of privatization}

- The government of the country should study the impact of privatization on enterprise performance, Macroeconomic and fiscal effects, Welfare consequences, Employment effects, and Wealth and income distribution ahead of implementation.

\section{vi. Identify factors for successful implementation}

- Before implementation, the government should identify factors for successful implementation of the program, such as commitment and ownership, ownership and competition, transparency, mitigating the social impact of privatization and environmental implications.

vii. Design action programme

Based on the SWOT analysis, an implementation program should be incorporated in the privatization strategy framework which includes:

- Classification of all the SOEs towards reducing its size via setting standards a set of benchmarks to classify SOEs into those who will remain in state hands, majority or minority shareholding by government, those who will be privatised to Bothe local and foreign investors or either of and those who will be liquidated.

- Define program phases, for the first five-year action which includes the number and extent of the divestiture of SOEs to be accomplished the first phase, this will spread out the immense implementation effort to efficiently utilize the limited resources.

- Define the policies to facilitate privatization. The policies may direct to improve the country's investment climate, ensure sustained investor interest, and bring optimal economic benefits to the country. Here the action program should be tailored to reduce the impact of the weaknesses and threats while exploiting the strengths and opportunities at the country's disposal, and hence, the three key procedures of establishing 
objectives, committing resources, and planning of action programs, should be included in the country's privatization strategy framework.

\section{References}

Achmad Joseph, Yaeesh Yasseen \& Rashied Small (2017): Business Valuations Seminar - August 2017; South Africa institute of professional accountants.

Appiah-Kubi, K. (2001). Privatization in Ghana. The Journal of Modern African Studies 39(2):197-229.

Árvai, Z., and Heenan, G., (2008). A Framework for Developing Secondary Markets for Government Securities. International Monetary Fund WP/08/174.

Barberis, N., Shleifer, A., \& Vishny, R. (1997). A Model of Investor Sentiment, 49. https://doi.org/10.3386/w5926

Beck T., Cull R. and Afeikhena J. (2005). Bank Privatization and Performance: Empirical Evidence from Nigeria, Policy Research Working Papers. February 2005.

Bell, S. (1999). Privatization through Broad Based Ownership Strategies: a more popular option? Washington D.C: World Bank notes no. 33.

Bennell, Paul (1997). Privatization in Sub-Saharan Africa: Progress and Prospects during the 1990s.World Development, Vol. 25, No. 11, pp.1785-1803.

Boubakri N., Cosset J.-C., Fischer K., Guedhami O. (2005). Privatization and bank performance in developing countries. Journal of Banking \& Finance 29 (2005) 2015-2041.

Bulow, J. \& Klemperer, P. (1996). Auctions versus Negotiations. The American Economic review 86 (1): 180 194. Cambridge, MA; New York, and Melbourne: Cambridge University Press.

Carter, M. Z. (2013). Privatization : A Multi-Theory Perspective, 14(2).

Cavaliere, A., Scabrosetti, S., Lavoro, N. D. I., Cavaliere, A., Scabrosetti, S., Pubblica, E., \& Pavia, U. (2006). Privatization and Efficiency : F rom Principals and Agents to Political Economy, (I).

Chole, E. (1993). Privatization and Deregulation in Ethiopian Industry: Journal of Ethiopian Studies, Vol. 26 , No. 1, pp. 33-58.

Clarke G., Cull R., Shirley M. (2005). Bank privatization in developing countries: A summary of lessons and findings. Journal of Banking \& Finance 29 (2005) 1905-1930.

Cummings, R. G., Martinez-vazquez, J., Mckee, M., \& Torgler, B. (2009). Journal of Economic Behavior \& Organization Tax morale affects tax compliance : Evidence from surveys and an artefactual field experiment, 70, 447-457. https://doi.org/10.1016/j.jebo.2008.02.010

Deneke, S. (2001). International Conference on African Development Private Sector Development in Ethiopia.

Dharwadkar, B., George, G., \& Brandes, P. (2000). Privatization in Emerging Economies : An Agency Theory Perspective, 650-669.

Draki, M. (2007). Privatization in Economic Theory, (November 2006), 103-118.

Estrin, S., \& Pelletier, A. (2016). Privatization in developing countries : What are the lessons of experience ? IZA Discussion Papers, 10297(November), 15-22. Retrieved from http://hdl.handle.net/10419/149156

Estrin, S., \& Pelletier, A. (2018). Privatization in developing countries: What are the lessons of recent experience? World Bank Research Observer, 33(1), 65-102. https://doi.org/10.1093/wbro/lkx007

Estrin, S. and Pelletier, A. (2015).Privatization in developing countries: What are the lessons of experience?

Fre'mond, O. \& Nellis, J. (1998). Pre-emptive Rights \& Privatization. Washington DC: World Bank Note no. 163.

Gebeyuhu, W. (2000). Has Privatization Promoted Efficiency in Ethiopia? A Comparative Analysis of Privatised Industries vis-avis State-owned and Other Private Industrial Establishments. Ethiopian Journal of Economics, 9(2), 109-133.

Gray, C.W. (1996).In Search for Owners: Privatization \& Corporate Governance in Transition Economies. The World Bank Research Observe, 11 (2): 179 - 195.

Harsch, E. (2000). Privatization Shifts Gears in Africa. African Recovery Online 14(1). http://dx.doi.org/10.4236/blr.2016.71002.

Jonathan R.M. and Enrico, C. (1995). Public Choice Theory and the Transition Market Economy in Eastern Europe: Currency Convertibility and Exchange Rates. Cornell International Law Journal: Vol. 28(2).

Joseph, A., Yasseen, Y., \& Small, R. (2017). Business Valuation - Concept, (August).

Julio O. de Castro and Klaus Uhlenbruck (1997). Characteristics of Privatization: Evidence from Developed, Less-Developed, and Former Communist Countries: Journal of International Business Studies, Vol. 28 , No. 1 (1st Qtr, 1997), pp. 123-143.

Kayizzi-Mugerwa, Steve (2002).Privatization in sub-Saharan Africa: On factors affecting implementation. WIDER Discussion Papers // World Institute for Development Economics (UNU-WIDER), No. 2002/12, ISBN 9291901431, UNU-WIDER, Helsinki.

Kikeri, S., \& Nellis, J. (2004). An assessment of privatization. World Bank Research Observer, 19(1), 87-118. https://doi.org/10.1093/wbro/lkh014

Kirk, W. C., \& Wishing, K. J. (2018). Fundamentals of the Asset-Based Business Valuation Approach, 3-14. 
Kivisto, J. (2007). Agency theory as a framework for the government-university relationship: Tampere sis university press.

Klein, M. (1998). Designing Auctions for Concessions-Guessing the Right Value to Bid \& Winner's Curse, Washington DC: World Bank Note no. 160.

Kornai, J. (2000). Making the Transition to the Private Ownership. Finance and Development 37(3):12-30.

Macey, J. R., \& Colombatto, E. (1995). Public Choice Theory and the Transition Market Economy in Eastern Europe : Currency Convertibility and Exchange Rates, 28(2).

Marsh, D., (1991). Public Administration Vol. 69 winter 1991 (459-480). Royal Institute of Public Administration ISSN 0033-3298.

Meheret, T. (n.d.). The Concept and Characteristics of Public Enterprises in Ethiopia : An Overview, 333-370.

Martimort, D. (2005). An Agency Perspective on the Costs and Benefits of Privatization, 1-47.

Megginson, William and Jeffry Netter. (2001). From State to Market: A Survey of Empirical Studies on Privatization. Forthcoming, Journal of Economic Literature.

Megginson, William, Robert Nash, and Matthias van Brandenburg. (1994). the Financial and Operating Performance of Newly Privatized Firms: An International Empirical Analysis. Journal of Finance. 49: 403452.

Mihret, T., (n.d). The Concept and Characteristics of Public Enterprises in Ethiopia: An Overview. DOI http://dx.doi.org/10.4314/mlr.v8i2.3

Nellis, J. (2008). Privatization in Africa. What has happened? What is to be done? In Roland, G. (ed.), Privatization: successes and failures.

Nellis, J. (n.d.). Time to Rethink Privatization in Transition Economies? John Nellis, (38).

Nelson, L.D. (1994). An assessment of the Russian voucher privatization program author: Virginia Commonwealth University Irina Y. Kuzes, Znanie-sila, Moscow.

Nicholas Barberis, Andrei Shleifer, Robert Vishny (1998). A model of investor sentiment. Journal of Financial Economics 49 (1998) 307-343.

Odukoya, A. O. (2007). Theoretical and Empirical Issues in Privatization : A Comparative Study of the British and Nigerian Experience, 14(1), 25-43.

Ogwezzy, M.C, \& Bello, S.A. (2013). Appraisal of the Philosophical, Political and Ideological Concept of Privatization: A Reflection on the Nigeria Experience. AGORA International Journal of Juridical Sciences, No. 4, pp. 116-133.

Paul Starr (1998). The Meaning of Privatization. Yale Law and Policy Review 6 (1988): 6-41.

Samwel M. S. Waigama (2008). Privatization Process and Asset Valuation a Case Study of Tanzania.

Selvam, J. (2007). Privatization program in Ethiopia : is the cause justified? African Renaissance, 4(1), 66-75.

Sheshinski, E., \& López-calva, L. F. (2003). Privatization and Its Benefits : Theory and Evidence, 49(Caer Ii), $429-459$.

Starr, P. (2018). The Meaning of Privatization, 1-10.

Steve Kayizzi-Mugerwa (2001). Globalisation, Growth and Income Inequality: The African Experience. OECD Development Centre Working Papers 186, OECD Publishing.

Studies, E. (2018). Institute of Ethiopian Studies Privatization and Deregulation in Ethiopian Industry Author ( s ): Eshetu Chole Source : Journal of Ethiopian Studies, Vol . 26 , No . 1 ( June 1993 ), pp . 33-58 Published by: Institute of Ethiopian Studies Stable URL : h, 26(1), 33-58.

Sunita Kikeri and John Nellis (2002). Privatization in Competitive Sectors: The Record to Date.

Tandon, P. (1995). Welfare Effects of Privatization: Some Evidence from Mexico, Boston University International, Law Journal, Vol. 13, No. 2, pp. 329-330.

Tanyi, G. B. (1997). Designing Privatization strategies in Africa: Law, Economics \& Practice, And London: Prager Publishers.

Tsegaw, E., (2016). The Legal Status of State-Owned Share Companies in Ethiopia. Beijing Law Review, 2016, 7 , 12-22. http://www.scirp.org/journal/blr.

United Nations (1993). Accounting, Valuation and Privatization, New York: United Nations Publications, $\mathrm{ST} / \mathrm{CT} / 157$.

Wallsten, S. (2001). An Econometric Analysis of Telecom Competition, Privatization, and Regulation in Africa and Latin America. The Journal of Industrial Economics 49:1-19.

Wagner, R. (2017). Mechanism for Market Valuation of State-Owned Enterprises without Privatization: Institutions for Development Sector Fiscal Management Division DISCUSSION paper n⿳0 idb-dp-524.

Waigama, S. M. S. (2008). PRIVATIZATION PROCESS AND ASSET VALUATION A case study of Tanzania Doctoral Thesis in.

Wallace, P. (2016). Privatization in Ethiopia, (916).

William Okecho (n.d). Uganda's Privatization Strategy: A Diagnosis

Wodajo, T., \& Senbet, D. (2017). Does Privatization Improve Productivity? Empirical Evidence from Ethiopia. 
International Journal of African Development, 2(1).

Wondwosen, T. W. (2009). Political Finance in Africa: Ethiopia as a Case Study. International Journal of Humanities and Social Sciences, 3(7).

Wright, M. D. (1993). A CRITIQUE OF THE PUBLIC CHOICE THEORY CASE FOR PRIVATIZATION : RHETORIC AND REALITY.

Yarrow, G., \& College, H. (1998). A Theory of Privatization, or Why Bureaucrats Still in Business are, 27(1), $157-168$.

Zenobia Ismail (2018). Privatization of State-owned Enterprises in Ethiopia since 1991. Helpdesk Report. K4D knowledge, evidence and learning for development. University of Birmingham 26 June 2018. 